\title{
Executive Power During the COVID-19 Pandemic
}

\author{
Rebecca Fotsch, JD
}

A s you may remember from civics class, the U.S. government consists of three branches: the legislative, which makes laws; the executive, which implements and enforces laws; and the judicial, which interprets the laws. With the legislative branch, U.S. citizens are accustomed to laws undergoing a long bill process and, once enacted, having a certain future effective date. Once effective, an administrative process then begins that allows interested parties to weigh in on the law and provides time for its implementation. This law-making process has served our states well; however, in times of disaster, governors have the power to issue executive orders when decisions must be made immediately to save lives.

\section{Gubernatorial Power}

The power allowing governors to issue executive orders emanates from the state constitution, state legislation, or case law, or it is simply implied from the powers awarded to the governor (National Governors Association, n.d.). Executive orders are a tool used by governors to, in essence, create law without the legislature's involvement. Executive orders can address numerous issues within the governor's administration, such as creating commissions or addressing administrative issues as well as responding to federal programs and requirements (National Governors Association, n.d.). However, arguably, the most widely recognized executive order are orders executed during times of emergency.

The recent COVID-19 pandemic demonstrates just how critical executive orders are to addressing public emergencies. Perhaps the greatest advantage to using executive orders is the speed with which they take effect. Unlike traditional legislation, executive orders can be issued swiftly to immediately address urgent matters (Gakh et al., 2013). Governors in all 50 states have issued a wide range of executive orders to address the ongoing coronavirus pandemic. For the purposes of this article, I will focus on executive orders addressing nursing regulation, including licensing, advanced practice registered nurse (APRN) practice, and nursing students.

\section{Licensure Hurdles}

Many of the first executive orders issued by governors addressed healthcare licensure. COVID-19 impacted certain parts of the country with greater force, particularly areas with large urban centers, like New York City, Chicago, Los Angeles, and Detroit. States needed ways to bring nurses into their state in order to care for the flood of COVID-19 patients as quickly as possible.

For example, New Jersey was hit hard by the pandemic. As of June 30, 2020, New Jersey had the third-highest number of cases as well as third-highest number of deaths from COVID-19 (New York Times, 2020). To recruit as many qualified nurses as possible in the shortest amount of time, New Jersey's Governor Phil Murphy issued an executive order authorizing the heads of agencies, including the New Jersey Board of Nursing (NJ BON), to waive those rules whose enforcement would negatively impact public safety (N.J. Exec. Order No. 20-103, 2020). The NJ BON decided to address out-of-state licensees in two ways, with the ultimate goal of hastening the mobility of nurses to the state.

First, the NJ BON issued a temporary rule waiver for outof-state nurse licensure applicants that negated the requirement that out-of-state nurses undergo a criminal background check or pay a fee for a temporary license (New Jersey Division of Consumer Affairs, 2020). This was done to expedite the licensure process. In fact, according to the New Jersey Division of Consumer Affairs website, the NJ BON will review temporary licensure application within 24 hours of submission (New Jersey Division of Consumer Affairs, 2020).

Second, New Jersey enacted the Nurse Licensure Compact (NLC) in 2019 but had yet to implement the law. The NLC is a compact between states that allows nurses to have one license in their state of residence and to use that one license to practice nursing in any of the compact states without obtaining additional nursing licenses. New Jersey had been in the process of implementing the NLC when the pandemic hit; at that point, the state decided that the immediate need for nurses was critical. As a tool to bring in qualified and vetted nurses, New Jersey decided to allow nurses who hold active, unencumbered compact licenses to practice in New Jersey under their multistate license (National Council of State Boards of Nursing, n.d.). This meant that compact nurses residing in 32 states were able to immediately travel to New Jersey and care for COVID-19 patients. 


\section{APRN Waivers}

In addition to licensure changes, states also recognized the importance of eliminating any regulatory barriers for APRNs to meet the increasing need for healthcare services during the pandemic. Currently, APRNs in Kentucky must enter into a collaborative agreement, or a contract with a physician, in order to prescribe controlled substances. For APRNs willing to assist with Kentucky's COVID-19 response, they would need to first find and enter into a contract with a physician licensed in Kentucky.

The Kentucky legislature recognized the process of finding a physician to enter into collaborative agreement, as well as the often restrictive terms of the agreement, as a roadblock to increasing access to care during the pandemic. The both timely and costly process would hinder nurses from coming to Kentucky to work. On March 30, 2020, the state passed legislation that allowed the Kentucky Board of Nursing to relax scope-of-practice regulations and allow healthcare providers to practice in all care settings (AN ACT Relating to the State of Emergency, 2020). On March 31, 2020, the secretary of the governor's executive cabinet then used the authority vested from the legislature to issue an order suspending collaborative agreements during the State of Emergency for COVID-19 (Brown, 2020). This applies to all APRNs practicing in Kentucky.

\section{Nursing Education and NCLEX Testing}

States' need for nurses during COVID-19 did not end with supplying out-of-state nurses. States also looked to their own nursing students to offer help during this time of crisis.

In Pennsylvania, Governor Wolf used his gubernatorial power to grant the Department of State's request to allow both out-of-state nurses as well as recently graduated nursing to quickly receive a permit to practice nursing in Pennsylvania during the pandemic. Out-of-state nurses can be issued a temporary permit to practice immediately upon application instead of undergoing the typical licensure process, which can require a significant amount of time to complete (Pennsylvania Department of State, 2020).

Although this move opened the door for many more nurses practicing in Pennsylvania during the pandemic, Pennsylvania expanded the pool of nurses even further by allowing newly graduated nursing students to practice in the state before they were able to sit for the NCLEX (Pennsylvania Department of State, 2020). This too was a temporary permit to practice available to nursing school graduates who were not able to take the NCLEX due to examination cancellations during COVID-19. In order to practice, the nursing graduate must be supervised by an $\mathrm{RN}$, and the permit will expire if the permit holder fails the NCLEX (Pennsylvania Department of State, 2020).

\section{Conclusion}

Governors have played a major role in facilitating access to care during the COVID-19 pandemic. The power to protect the state during times of disaster is vested in the gubernatorial role, and governors have demonstrated that power by issuing orders that have affected many areas of nurse regulation, including licensure, advanced practice nursing, and nursing education. We can only hope that such measures are not needed again in the near future.

\section{References}

AN ACT Relating to the State of Emergency in Response to COVID-19 and Declaring an Emergency, KY S.B. 150 (2020, March 30). https://apps.legislature.ky.gov/record/20RS/sb150.html

Brown, J. M. (2020, March 31). Order. Office of the Governor. https:// kbn.ky.gov/Documents/Order\%20_KBN_APRNs.pdf

Gakh, M., Vernick, J. S., and Rutkow, L. (2013). Using gubernatorial executive orders to advance public health. Public Health Reports, 128(2), 127-130. https://doi.org/10.1177/003335491312800208

N.J. Exec. Order No. 20-103 (2020, March 9).

National Council of State Boards of Nursing. (n.d.). Nurse Licensure Compact (NLC). https://www.ncsbn.org/nurse-licensure-compact. htm

National Governors Association. (n.d.). Governors' powers and authority. https://www.nga.org/consulting-2/powers-and-authority/

New Jersey Division of Consumer Affairs. (2020, May 30). Temporary emergency license for out-of-state practitioners. https://www. njconsumeraffairs.gov/Pages/Temporary-Emergency-License-forOut-of-State-Practitioners.aspx

New York Times. (2020). Coronavirus in the U.S.: Latest map and case count. Accessed June 30, 2020. https://www.nytimes.com/ interactive/2020/us/coronavirus-us-cases. html

Pennsylvania Department of State. (2020, March 18). Issuance of temporary licenses to health care practitioners not licensed in Pennsylvania to be expedited during coronavirus emergency. https://www.dos. pa.gov/Documents/2020-03-18-Temporary-Licenses-Out-of-StatePractitioners.pdf

Rebecca Fotsch, JD, is the Director, State Advocacy and Legislative Affair, National Council of State Boards of Nursing, Chicago, Illinois. 